\title{
Fuel consumption and air emissions in one of the world's largest commercial fisheries
}

\author{
Chassot Emmanuel 1, 2, * Antoine Sharif ${ }^{~}$, Guillotreau Patrice ${ }^{3,4}$, Lucas Juliette ${ }^{1}$, Assan Cindy ${ }^{1}$, \\ Marguerite Michel ${ }^{1}$, Bodin Nathalie 1,2,5
}

${ }^{1}$ Seychelles Fishing Authority (SFA), Victoria, Mahé, Seychelles

${ }^{2}$ Research Institute for Sustainable Development (IRD), Victoria, Mahé, Seychelles

3 University of Nantes, LEMNA, Nantes, France

${ }^{4}$ MARBEC, Univ Montpellier, CNRS, Ifremer, IRD, Sète, France

${ }^{5}$ Sustainable Ocean Seychelles, Beaubel, Seychelles

*Corresponding author : Emmanuel Chassot, email address : emmanuel.chassot@ird.fr

\begin{abstract}
:
The little information available on fuel consumption and emissions by high seas tuna fisheries indicates that the global tuna fleet may have consumed about $2.5 \mathrm{Mt}$ of fuel in 2009 , resulting in the production of about $9 \mathrm{Mt}$ of CO2-equivalent greenhouse gases (GHGs), i.e., about 4.5-5\% of the global fishing fleet emissions. We developed a model of annual fuel consumption for the large-scale purse seiners operating in the western Indian Ocean as a function of fishing effort, strategy, and vessel characteristics based on an original and unique data set of more than 4300 bunkering operations that spanned the period 20132019. We used the model to estimate the total fuel consumption and associated GHG and SO2 emissions of the Indian Ocean purse seine fishery between 1981 and 2019. Our results showed that the energetic performance of this fishery was characterized by strong interannual variability over the last four decades. This resulted from a combination of variations in tuna abundance but also changes in catchability and fishing strategy. In recent years, the increased targeting of schools associated with fish aggregating devices in response to market incentives combined with the IOTC management measure implemented to rebuild the stock of yellowfin tuna has strongly modified the productivity and spatio-temporal patterns of purse seine fishing. This had effects on fuel consumption and air pollutant emissions. Over the period 2015 to 2019, the purse seine fishery, including its support vessel component, annually consumed about 160,000 t of fuel and emitted 590,000 t of CO2-eq GHG. Furthermore, our results showed that air pollutant emissions can be significantly reduced when limits in fuel composition are imposed. In 2015, SO2 air pollution exceeded $1500 \mathrm{t}$, but successive implementation of sulphur limits in the Indian Ocean purse seine fishery in 2016 and 2018 have almost eliminated this pollution. Our findings highlight the need for a routine monitoring of fuel consumption with standardized methods to better assess the determinants of fuel consumption in fisheries and the air pollutants they emit in the atmosphere.
\end{abstract}

\section{Graphical abstract}




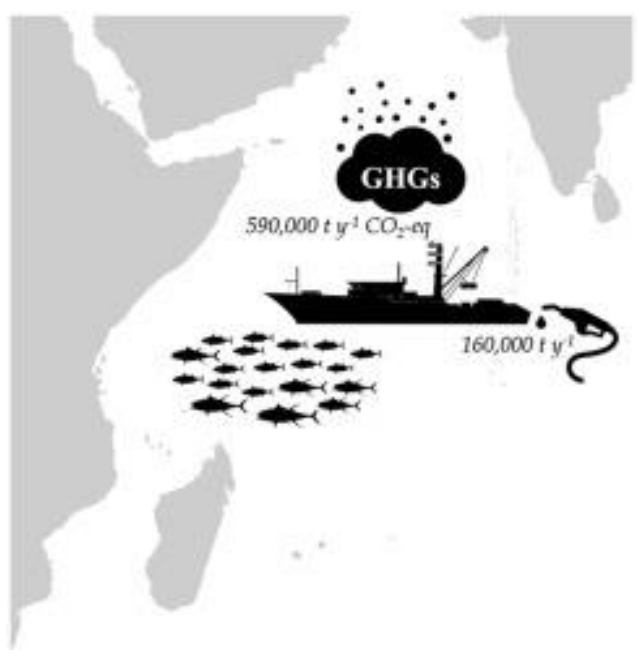

\section{Highlights}

- We modelled the annual fuel consumption in tuna purse seiners of the Indian Ocean. Days at sea, numbers of operations, vessel length and age affect fuel consumption. Fuel Use Intensity and consumption showed strong variability over 1981 to 2019. Greenhouse gas emissions were about $600,000 \mathrm{t} \mathrm{y}^{-1}$ of $\mathrm{CO}_{2}$-eq over 2015 to 2019. Sulphur limits reduced annual $\mathrm{SO}_{2}$ emissions from $>1500 \mathrm{t}$ to almost none since 2018 .

Keywords : Air pollution Fish aggregating device (FAD), Energy use Greenhouse gas (GHG), Sulphur dioxide, Tuna purse seine fisheries 


\section{Introduction}

47 Oceangoing ships constitute a significant source of air pollution through the emission of

48 greenhouse gases ( $\mathrm{GHGs}$ ) such as carbon dioxide $\left(\mathrm{CO}_{2}\right)$ and nitrous oxide $\left(\mathrm{N}_{2} \mathrm{O}\right)$, and other air

49 pollutants such as sulphur dioxide $\left(\mathrm{SO}_{2}\right)$ (Corbett and Fischbeck, 1997; Corbett et al., 1999).

50 Global shipping emissions have major effects on the environment, including ocean acidification

51 and contribution to climate change, and on human health (Corbett et al., 2007; Jägerbrand et

52 al., 2019; Tian et al., 2013). With about 2.5 million motorized vessels out of 4.6 million vessels in

53 operation (FAO, 2018; Rousseau et al., 2019), the global fishing fleet annually consumes about

$54 \quad 30-40$ million tonnes (Mt) of fuel and accounts for more than $1 \%$ of the global marine fuel

55 demand (Parker et al., 2018; Tyedmers et al., 2005). Global emissions from fuel combustion by

56 fishing vessels have been estimated at about 180-200 Mt of $\mathrm{CO}_{2}$-equivalent GHGs every year

57 (Parker et al., 2018). Furthermore, total emissions related to fishing go beyond the direct

58 emissions of fuel combustion because of indirect effects of upstream and downstream

59 activities, e.g., emissions generated during fuel processing and refining, fish product packaging

60 and transport (Winebrake et al., 2007). Fishing and water transport are therefore considered

61 among the most air-polluting industries, per unit of wealth created, in particular for $\mathrm{CO}_{2}$ and

$62 \mathrm{SO}_{2}$ (Bagoulla and Guillotreau, 2020). To improve air quality and global health, global sulphur

63 limits of $0.5 \%$ (mass/mass) in fuel oil have been recently imposed by the International Maritime

64 Organization (IMO) under the MARPOL convention (Annex VI) to reduce the emissions of both

65 sulphate aerosols and sulphur-containing particles (Chu Van et al., 2019).

66 Industrial tuna fisheries are one of the most highly capitalized fisheries in the world (Miyake et

67 al., 2010). High seas fishing vessels, typically longer than $25 \mathrm{~m}$, travel long distances to search 
68 and catch highly migratory tuna and billfish widely distributed across the world's oceans

69 (Fonteneau, 2010). Energy costs make up to $20 \%$ or more of total running costs in the high seas

70 fishing industry (Miyake et al., 2010). However, little information is available on fuel

71 consumption and emissions by high seas tuna fisheries. This said, a survey-based study

72 indicated that the global tuna fleet may have consumed about $2.5 \mathrm{Mt}$ of fuel in 2009 , resulting

73 in the production of about $9 \mathrm{Mt}$ of $\mathrm{CO}_{2}$-equivalent $\mathrm{GHGs}$, i.e., about $4.5-5 \%$ of the global fishing

74 fleet emissions (Tyedmers and Parker, 2012). Although large-scale purse seiners represent a

75 very small component of the global tuna fleet ( 700 vessels in 2020; Justel-Rubio and Recio

76 (2020)), they accounted for more than two thirds of the global catch of tuna since the late

77 2000s. In 2009, the global tuna purse seine fishery was responsible for the release of more than

$783 \mathrm{Mt}$ of $\mathrm{CO}_{2}$-equivalent GHGs into the atmosphere (R. W. R. Parker, Hartmann, et al., 2015).

79 The global tuna purse seine fishery has significantly changed over the last decade. The purse

80 seine catches of tropical tuna increased from about $2.8 \mathrm{Mt}$ in the late 2000 s to more than 3.2

81 Mt in the late 2010s, with about two thirds of the catch coming from fish aggregating devices

82 (FAD) and the rest from free-swimming schools (FSC) and schools associated with dolphins

83 (Taconet et al., 2018). In the Indian Ocean, the catch of the tuna purse seine fishery, composed

84 of about 50 vessels larger than $65 \mathrm{~m}$, increased from $280,000 \mathrm{t}$ in the late 2000 s to almost

$85500,000 \mathrm{t}$ in 2018 (Fiorellato et al., 2019). In particular, the advent and increasing use of echo-

86 sounder buoys attached to the FADs deployed at sea has greatly increased the efficiency and

87 catchability of purse seiners over the last decade (Lopez et al., 2014; Wain et al., 2020).

88 Furthermore, 20 support vessels assist the purse-seine fishing fleet by maintaining a network of

89 FADs. These support vessels have proved to be instrumental in increasing fishing success, 
90 although they consume additional fuel energy and produce more GHG emissions (Assan et al.,

91 2015; Ramos et al., 2010). Over the last decades, an increasing proportion of FAD-caught tuna

92 has been observed in the Indian Ocean purse seine fishery. Since 2017, the use of FADs has

93 been further accentuated by a shift in the fishing strategy to target more skipjack tuna

94 (Katsuwonus pelamis) (Assan et al., 2019; Baez et al., 2018; Floch et al., 2019). This change

95 occurred following the implementation of a total allowable catch on yellowfin tuna (Thunnus

96 albacares) by the Indian Ocean Tuna Commission (IOTC) with the aim of rebuilding the

97 yellowfin tuna stock. Yellowfin tuna compose the large majority of FSCs while tuna schools

98 associated with FADs are dominated by skipjack tuna (Fonteneau et al., 2013). Such a change in

99 fishing strategy may have affected the fuel consumption and air pollutant emissions as purse

100 seiners targeting schools associated with FADs have been shown to consume more fuel per ton

101 landed than purse seiners targeting FSCs at global scale (R. W. R. Parker, Vázquez-Rowe, et al.,

102 2015).

103 In this context, the overarching objective of the present study was to estimate with more

104 accuracy the $\mathrm{GHG}$ and $\mathrm{SO}_{2}$ emissions of the tuna purse seine fishery of the Indian Ocean over

105 the period 1981 to 2019 and assess how they vary with fleet structure, fishing strategy and

106 productivity. First, we developed a model of fuel consumption of tropical tuna purse seiners

107 based on a unique large data set of bunkering operations that took place in the Seychelles

108 between 2013 and 2019. Secondly, we used the model to estimate the direct total fuel

109 consumption and associated GHGs and $\mathrm{SO}_{2}$ emissions for the western Indian Ocean purse seine

110 fishery over the last four decades (1981-2019), including the fuel consumed by the fleet of 
111 support vessels. Finally, we assessed the extent of the reduction in $\mathrm{SO}_{2}$ emissions following the

112 mandated reduction in sulphur content of the marine diesel oil delivered in the Seychelles.

\section{Materials \& Methods}

\section{$114 \quad$ Fuel data}

115 All bunkering operations in Port Victoria are recorded by the Seychelles Petroleum Company

116 (SEYPEC) and include the vessel name, type of gasoil (i.e., sulphur content), volume (I) and

117 weight $(\mathrm{t})$ delivered, and the date and location of delivery. All purse seiners and support vessels

118 considered in the study use the same marine diesel oil, a marine fuel composed of various

119 blends of distillates and heavy fuel oil. Except for sulphur, the general composition of the

120 marine fuel delivered in Port Victoria has not varied much over the last four decades. The

121 storage capacity of fuel varies with vessel size, i.e., between $370-1,000 \mathrm{~m}^{3}$ and $90-160 \mathrm{~m}^{3}$ for

122 purse seiners and support vessels, respectively. The data set available for the study covered the

123 period 2013 to 2019 and included a total of 3,676 and 703 bunkering operations for 52 purse

124 seiners and 29 support vessels, respectively. Sulphur content in the fuel delivered to the purse

125 seiners and support vessels calling on Port Victoria was reduced from $0.5 \%$ to $0.05 \%$ on the $1^{\text {st }}$

126 of March 2016 and from $0.05 \%$ to $0.005 \%$ on the $15^{\text {th }}$ of May 2018.

\section{Fisheries data}

128 The purse seine fleet based in Port Victoria, Seychelles, represents more than $90 \%$ of the total

129 purse seine catch of the Indian Ocean over the period 1981 to 2019 (Assan et al., 2019; Baez et

130 al., 2018; Floch et al., 2019; Kawol et al., 2019). The activities of the purse seiners operating in

131 the western Indian Ocean have been monitored since the early 1980s by the Seychelles Fishing 
132 Authority (SFA) in collaboration with the French national Research Institute for Sustainable

133 Development (IRD) and the Spanish national Institute of Oceanography (IEO). The monitoring

134 consists of the collection and processing of fisher' logbooks, landings and sales notes, and

135 sampling of the catch at unloading. Information on landings is recorded for each trip. All purse

136 seiners are equipped with a Vessel Monitoring System (VMS) and monitored at sea by their

137 respective national fisheries administrations. For each fishing operation, the catch by species

138 and type of tuna school association (i.e., FSC and FAD) are recorded in the logbook. Days at sea

139 constitute the standard effort unit to monitor purse seine fishing effort (FAO, 1997). Purse

140 seiner logbook data constitute the basis of the aggregated catch-effort data reported to the

141 IOTC and were assumed to be comprehensive and accurate in this study. By contrast, support

142 vessel logbooks were incomplete or missing, preventing the computation of the annual number

143 of days at sea for this component of the purse seine fishery.

\section{Vessel fuel consumption}

145 The fishing activities of purse seiners that operated in the western Indian Ocean from 2013 to

1462019 were linked with the bunkering operations that took place at Port Victoria, Seychelles,

147 during the same period. We selected a subset of purse seiners that unloaded and transshipped

148 all their catch in Port Victoria, assuming that the vessels did not purchase fuel elsewhere. In

149 most cases, the vessels take the opportunity to refuel during unloading operations. We

150 considered that the fuel delivered in a given year was representative of the landings of the year

151 although a few fishing trips may span two years. 
152 We used generalized additive models (GAMs) to examine the relationship between the annual

153 quantity of fuel $(F ; \mathrm{t})$ delivered to the subset of selected purse seiners as a function of vessel

154 length overall $(L O A ; \mathrm{m})$, annual number of days at sea $(D)$ and number of fishing sets on FSCs

$155\left(S_{F S C}\right)$ and FADs $\left(S_{F A D}\right)$ in order to account for differences in fishing effort and strategy. By

156 using local smoothers, GAMs make no a priori assumptions about the nature of the associations

157 between predictors and response variables (Hastie and Tibshirani, 1990). The period of

158 construction $(C)$ of each purse seiner was included in the model as a categorical covariate (i.e.,

159 1970-1980s, 1990-2000s and 2010s) to account for technological improvements in diesel

160 engines and vessel design. Year $(Y)$ was finally included as a categorical covariate to account for

161 changes in tuna abundance and accessibility, e.g., changes in access opportunities related to

162 fisheries agreements. The general form of the model fitted to the fuel data was:

163

$$
F_{v, Y}=s\left(L O A_{v}\right)+C_{v}+s\left(D_{v, Y}\right)+s\left(S_{F A D_{v, Y}}\right)+s\left(S_{F S C_{v, Y}}\right)+Y+\epsilon_{v, Y}
$$

164 Where $v$ and $Y$ indicate vessel and year, respectively and the model residuals $\epsilon_{v, Y}$ were

165 assumed to be independent and identically distributed normal random variables with mean

166 zero and constant variance. Model fitting and the automatic selection of degrees of freedom

167 for the regression splines were performed using the generalized cross-validation method

168 (Wood, 2011). Assumptions of homoscedasticity and Gaussian distribution were checked

169 through the residuals.

170 Effects of vessel size were assessed by comparing predictions of annual fuel consumption for

171 the smallest purse seiner $($ LOA $=67.3 \mathrm{~m})$, a purse seiner of mean length (LOA $=89.7 \mathrm{~m})$, and the

172 largest purse seiner of the fleet $(L O A=116 \mathrm{~m})$, all built in the 1990s, having operated over 273 
173 days and having made 223 and 51 sets on FAD and FSC, respectively, corresponding to the

174 mean values observed in the data set. Model predictions were also performed to assess the

175 influence of the fishing strategy (i.e., FSC vs. FAD) on purse seiner's annual fuel consumption.

176 For these simulations, we considered a purse seiner built in the 1990s of mean length $89.7 \mathrm{~m}$ in

177 operation for 273 days at sea (i.e. the mean value observed in the data set) for a number of sets

178 varying between 0 and 141 made either on FADs or FSCs and corresponding to the range of

179 values observed for FSCs in the data set.

180 Statistical analyses were performed in R version 3.6.3 (R Core Team 2020).

\section{Energetic performance}

182 The Fuel Use Intensity (FUI), i.e., annual volume of fuel (I) consumed per ton of wet weight

183 landings, was used to describe and assess the environmental performance of the purse seine

184 fishery (Parker et al., 2018; R. W. R. Parker, Hartmann, et al., 2015). The annual value of FUI was

185 computed for all purse seiners to describe the variability between vessels. The fuel consumed

186 by the support vessels could not be included in the individual FUI of the purse seiners as they

187 were generally assisting several vessels and this information was not available for most years of

188 the study period. To account for this additional fuel consumption, the annual FUI values were

189 scaled up by the FUI of the support vessels computed as the ratio between the total annual

190 quantity of fuel consumed by this fleet segment and the total landings of the fishery.

\section{GHG and $\mathrm{SO}_{2}$ emissions}

192 Emissions of $\mathrm{GHGs}$ and $\mathrm{SO}_{2}$ from marine fuel combustion are considered to be mostly

193 dependent on fuel contents while engine and combustion technology may have more influence 
194 on the release of other pollutants such as nitrogen oxides (Holloway et al., 2006; Winnes and

195 Fridell, 2009). GHGs emitted from water-borne navigation include $\mathrm{CO}_{2}, \mathrm{~N}_{2} \mathrm{O}$, methane $\left(\mathrm{CH}_{4}\right)$,

196 carbon monoxide (CO), non-methane volatile organic compounds (NMVOCs), particulate matter

197 (PM), and oxides of nitrogen ( $\mathrm{NO}_{\mathrm{x}}$ ) (Waldron et al., 2006). There is currently little information

198 available about the emissions of each GHG by large-scale purse seiners and their associated

199 support vessels. Recently, Parker et al. (2015) estimated a total GHG-to-fuel ratio of $3.1 \mathrm{~kg} \mathrm{CO}_{2}-$

200 eq per litre of fuel consumed for the purse seine fishery. This emission factor reflects both the

201 direct emissions of the marine distillate fuel used by the vessels $\left(2.8 \mathrm{~kg} \mathrm{CO}_{2}\right.$-eq $\left.\mathrm{l}^{-1}\right)$ and the life

202 cycle emissions from mining, processing, and transporting, to packaging $\left(0.3 \mathrm{~kg} \mathrm{CO}_{2}\right.$-eq $\left.{ }^{-1}\right)$

203 (Hospido and Tyedmers, 2005; Hospido et al., 2006; Parker and Tyedmers, 2015). This emission

204 factor is very similar to that of other studies (Dalsøren et al., 2009; Ziegler and Hansson, 2003)

205 and it has been used for a large range of fisheries worldwide (Parker et al., 2018; R. W. R.

206 Parker, Hartmann, et al., 2015).

207 In absence of detailed information, we followed the approach of Parker et al. (2015) and

208 considered a mean emission factor of $3.7 \mathrm{t}$ of $\mathrm{CO}_{2}$-eq per $\mathrm{t}$ of fuel consumed based on the mean

209 density of 0.835 of the fuel delivered in Port Victoria between 2013 and 2019. To account for

210 variability in GHG emissions, we considered a coefficient of variation of $10 \%$ for the emission

211 factor, i.e., we assumed that $95 \%$ of the values of the emission factor were comprised between

2123 and $4.4 \mathrm{t}$ of $\mathrm{CO}_{2}$-eq per $\mathrm{t}$ of fuel consumed. While the variance of the $\mathrm{CO}_{2}$ emission factor is

213 considered small for marine diesel (Waldron et al., 2006), emissions associated with the

214 transport of tuna from the fishing grounds to the processing factories are expected to vary due

215 to their location all over the world (Miyake et al. 2010). Furthermore, the variability in 
216 emissions may stem from differences in packaging since tuna caught with purse seine can be

217 processed in different products: canned chunks and flakes, loins, and steaks. Confidence

218 intervals around GHG estimates were computed by boostrap resampling $(n=500)$ in the

219 distributions of fuel predictions and emission factor assuming that they were normally

220 distributed.

221 For $\mathrm{SO}_{2}$, emissions were assumed to be directly proportional to the sulphur content in the fuel,

222 i.e., $0.01,0.001$, and $0.0001 \mathrm{t}$ per $\mathrm{t}$ of fuel consumed for $0.5 \%, 0.05 \%$, and $0.005 \%$ sulphur,

223 respectively (Corbett et al., 1999). Since the model of fuel consumption was based on annual

224 data, the successive changes in sulphur content were assumed to have taken place in January

2252016 and 2018, respectively. The reduction in sulphur was also assumed to have occurred in the

226 other fishing ports of call of the Port Victoria-based purse seiners, i.e., Diego Suarez

227 (Madagascar) and Port-Louis (Mauritius). The landings made at these ports represented less

228 than $2.5 \%$ of the landings of the fleet over the period 2016 to 2019. Information on fishing

229 effort and operations was available for all large-scale purse seiners that operated in the

230 western Indian Ocean and were based in Port Victoria over the last four decades (1981-2019).

231 We used the model of annual vessel fuel consumption to predict the total fuel consumed and

232 associated GHG and $\mathrm{SO}_{2}$ emissions for all Port Victoria-based purse seiners from 1981 to 2019.

233 We included the fuel consumed by the support vessels from 2013 to 2019, assuming they

234 bunkered only in Port Victoria during that period. Statistical analyses were performed in R

235 version 3.6.3 (R Core Team 2020). 


\section{Results}

\section{Fuel delivery in Port Victoria}

238 From 2013 to 2019 , mean total weights of $139,000 t(S D=20,000 t)$ and $8,000 t(S D=3,000 t)$ of

239 fuel were delivered annually to the purse seiners and support vessels calling on Port Victoria,

240 Seychelles, respectively (Table 1). Over that period, the support vessels represented 5.4\% of the

241 total fuel purchased in Port Victoria. For purse seiners, the mean fuel quantity delivered during

242 an operation was $264 \mathrm{t}$ and the maximum was $858 \mathrm{t}$ (Table 1). For support vessels, the mean

243 was $79 \mathrm{t}$ and the maximum was $176 \mathrm{t}$.

\section{Selected data set}

245 More than $95 \%$ of all fish caught by the purse seine fishing fleet operating in the western Indian

246 Ocean from 2013 to 2019 were landed at Port Victoria, Seychelles. We found 168 annual

247 records of 44 purse seiners that exclusively unloaded and transshipped in Port Victoria,

248 providing an opportunity to link fishing effort and activities with fuel consumption. This data set

249 represented $63 \%$ of all days at sea, $65 \%$ of fishing sets, and $67 \%$ of landings of the Port Victoria

250 based-purse seine fishing fleet over the period 2013 to 2019.

251 The mean annual fishing effort for the selected vessels decreased between 2013-2016 and

252 2017-2019 following the implementation of the rebuilding plan for the Indian Ocean yellowfin

253 tuna stock (Table 2). Between the two periods, the mean annual number of fishing sets

254 remained stable but the proportion of sets on FADs increased from $77 \%$ to $86 \%$ in 2017 to

255 2019. The mean weight of fuel consumed annually by one purse seiner decreased from about

$2564,000 \mathrm{t}$ in 2013 to about 3,000 t in 2019 (Table 2). 


\section{Variability in fuel consumption}

258 We found that vessel size, fishing effort, and fishing sets for both types of tuna school

259 associations as well as the period of vessel construction significantly explained the variability in

260 purse seiners' fuel consumption while there were no significant differences between years of

261 activity. The final model explained $88.5 \%$ of the total variance of the annual fuel consumed by

262 purse seiners and each effect was significant (Table 3). After accounting for differences in vessel

263 length, we found that purse seiners built throughout the 1970s and 1980s had the highest fuel

264 consumption. They consumed $943 \mathrm{t}$ more fuel annually than vessels built in the 1990s-2000s

265 and $212 \mathrm{t}$ more than vessels built after the 2010s. Hence, the most recent vessels were found to

266 annually consume $731 \mathrm{t}$ more fuel than the ones built during the 1990s-2000s. This is explained

267 by the increased requirements in energy to store part of the catch at ultra-low temperature to

268 improve fish quality. Some purse seine fishing companies have recently developed new markets

269 of higher value (e.g., loins, sashimi) based on improved handling and storage practices. Besides,

270 the annual fuel consumption was found to linearly increase with the number of fishing

271 operations on FADs, i.e., by $3.8 \mathrm{t}$ of fuel for each additional set on FADs, while the positive

272 effects of length overall, days at sea, and number of sets on FSCs on fuel consumption were

273 found to be non-linear (Fig. 1).

274 Vessel length substantially increased the annual quantity of fuel consumed by a purse seiner.

275 Considering the mean annual values of 273 days spent at sea, 223 sets on FADs and 51 sets on

276 FSCs observed in the data set, the mean annual fuel consumption (lower and upper bounds of

277 the 95\% confidence interval) was estimated at 2,044 $t(1,792-2,297 \mathrm{t})$ for small-sized purse 
278 seiners, 2,682 t (2,392-2,971 t) for medium-sized purse seiners, and 4,360 t $(4,097-4,623 \mathrm{t})$ for

279 large-sized purse seiners built in 2001 (Fig. 2).

280 The fishing strategy defined by the type of school association targeted was found to affect fuel

281 consumption, with FAD-fishing resulting on average in more fuel consumed than FSC-fishing.

282 For 60 fishing sets made either on FSC- or FAD-associated schools, model predictions indicated

283 that the annual fuel consumption would be $1,868 \mathrm{t}(1,515-2,221 \mathrm{t})$ for FSC sets and 2,135

$284(1,746-2,523 \mathrm{t})$ for FAD sets (Fig. 3). Nevertheless, the difference was found to be not

285 significant as the confidence intervals of the predictions overlapped, showing the large

286 variability in fuel consumption estimates between vessels.

$287 \quad$ Fuel Use Intensity

288 The FUI in the western Indian Ocean purse seine fishery showed a large variability over the last

289 four decades. The median FUI was larger than $1,000 \mathrm{t}^{-1}$ in the early 1980 s during the initial

290 phase of development of the fishery and then showed an overall decreasing trend until 2003

291 when it reached a minimum of $364 \mathrm{It}^{-1}$ (Fig. 4). The FUl showed large interannual variability

292 during the 2000s and 2010s and had median values lower than $500 \mathrm{I} \mathrm{t}^{-1}$ in 2018 and 2019. The

293 support vessels contributed to between $3 \%$ and $7 \%$ of the FUI of the purse seine fishery

294 between 2013 and 2019.

295 The annual estimates of FUI were found to differ highly between purse seiners. For instance, in

2962015 , the standard deviation of the FUI in the fleet was $210 \mathrm{I} \mathrm{t}^{-1}$, with values ranging from less

297 than $500 \mathrm{It}^{-1}$ to more than $800 \mathrm{It}^{-1}$. Furthermore, the purse seiners showed some major

298 changes in FUl over time. For instance, a purse seiner that was present in the fishery between 
2991984 and 2019 was described by a standard deviation of $132 \mathrm{It}^{-1}$ for a mean value of FUI of 436

$300 \quad \mathrm{It}^{-1}$ over the period, i.e., a coefficient of variation of $30 \%$.

\section{Historical changes in the fishery}

302 After an initial period of exploration in the very early 1980s, a large number of purse seiners

303 arrived in the Indian Ocean from the Atlantic Ocean in 1984, rapidly increasing the fishing effort

304 and the number of fishing operations. These were mainly conducted on FSC tuna at that time

305 (Fig. 5a-c). The annual effort of the fishery increased with some variability to more than 15,000

306 days at sea in 1997, before decreasing to about 12,000 days in 2004 (Fig. 5a,c). Between 1984

307 and 1997, the FAD component of the fishery steadily developed. The fishery experienced a

308 major decrease in effort and sets on FSCs due mainly to the piracy threat in 2008 to 2010 (Fig.

$3095 a, c)$. The effort increased again in 2016 to almost 14,000 days at sea while the sets on FADs

310 showed a massive increase, from about 7,500 annually over the period 2013 to 2015 to more

311 than 10,000 from 2016 to 2018 (Fig. 5b). In the last years (2017 to 2019), the yellowfin tuna

312 catch limit on the purse seine fishery resulted in a decrease in the number of days spent at sea

313 combined with a drop in the targeting of FSC tuna (Fig. 5a,c).

314 In addition to changes in fishing effort and operations, the purse seine fishery showed some

315 major changes in vessel technical characteristics that affected fuel consumption throughout the

316 whole period. In particular, larger vessels consumed more fuel (see section Variability in fuel

317 consumption) and the fishery showed a steady increase in vessel size over the last four

318 decades. The mean vessel length increased from less than $60 \mathrm{~m}$ in the early 1980 s to more than

$31990 \mathrm{~m}$ in 2019 (Fig. 5d). In addition, the period of construction was found to affect fuel 
320 consumption (see section Fuel Consumption), which is likely due to technological

321 improvements in vessel and engine design over the last decades. The mean year of

322 construction, used as a metric of age of the vessels, steadily increased over time from a mean

323 of 1978 in the 1980 s to 1999 in the 2010s (Fig. 5e). These changes reflected an aging of the

324 fleet from about 5-6 years old at the inception of the fishery in the early 1980s to about 15

325 years old on average in the 2000 s and early 2010 s. Some new vessels came into the fleet in

3262015 , reducing the mean age from a maximum of 16.2 years old in 2013 to 13.5 years in 2015

327 (Fig. 5f).

328 Total fuel consumption and air emissions

329 The estimated quantity of fuel consumed by the purse seine fishery in operation in the western

330 Indian Ocean showed strong interannual variability over the last four decades (1981-2019) in

331 relation to major changes in the fishing effort and activities (Fig. 6a). GHG and $\mathrm{SO}_{2}$ emissions

332 were assumed to be proportional to fuel consumption and therefore showed similar temporal

333 patterns as fuel consumption over the last decades (Fig. $\mathbf{6 b}$-c). The development of the fishery

334 in the 1980 s resulted in a rapid increase of the fleet fuel consumption to about $110,000-$

335125,000 t over the decade between 1985 and 1994 (Fig. 6). In the meantime, the annual GHG

336 and $\mathrm{SO}_{2}$ emissions increased to about 425,000 t of $\mathrm{CO}_{2}$-eq $(\mathrm{SD}=31,522 \mathrm{t})$ and $1,100 \mathrm{t}(\mathrm{SD}=86$

337 t), respectively. Fuel consumption and emissions then increased with some variability to reach a 338 peak in 2006 at about $165,000 \mathrm{t}$ of fuel, $610,000 \mathrm{t}$ of $\mathrm{CO}_{2}$-eq GHG and 1,700 $\mathrm{t}$ of $\mathrm{SO}_{2}$ (Fig. 6). The

339 high values of fuel consumption and emissions observed during 2003 to 2006 seemed to mainly

340 be driven by the large number of fishing sets on FSCs during that period (Fig. 5c). Fuel

341 consumption and associated emissions then showed major declines to $106,000 \mathrm{t}$ of fuel, 
342428,000 t of $\mathrm{CO}_{2}$-eq GHG and 1,100 t of $\mathrm{SO}_{2}$ in 2010 in relation to a sharp decline in the overall

343 effort and activities of the purse seine fleet. When the piracy risk was reduced, the vessels

344 came back to the fishery and increased their overall fishing effort, in particular towards a

345 massive use of FADs and support vessels. Consequently, the air emissions increased to reach

346 more than 660,000 t of $\mathrm{CO}_{2}$-eq in 2016 . In recent years, fuel consumption and $\mathrm{GHG}$ emissions

347 decreased following the implementation of the yellowfin tuna catch limit. Meanwhile, $\mathrm{SO}_{2}$

348 emissions dropped to about $180 \mathrm{t}$ in 2016 and $15 \mathrm{t}$ in 2019 following the successive reductions

349 in the sulphur content of fuel imposed in 2016 and 2018.

350 Discussion

351 Our results provide a four decade perspective on the air pollutant emissions of one of the

352 world's largest commercial fisheries, the Indian Ocean purse seine fishery, responsible for

353 about half a Mt of tropical tuna catch in 2018. Based on an original and unique data set of more

354 than 4,300 bunkering operations spanning the period 2013-2019, we developed a model of

355 annual fuel consumption for a subset of large-scale purse seiners based in Port Victoria,

356 Seychelles, as a function of fishing effort, strategy and vessel characteristics. Based on our

357 model that explained almost $90 \%$ of the variability in purse seiners' annual fuel consumption,

358 our findings are threefold. First, we showed that the energetic performance of the Indian Ocean

359 purse seine fleet quantified with the FUI showed strong interannual variability. This is mainly

360 explained by the variability in fishing success due to a combination of variations in tuna

361 abundance and catchability, changes in accessibility and changes in fishing grounds, and

362 changes in fishing strategy. In particular, the increased targeting of FAD-associated schools in 
363 response to market incentives (e.g., sale price of skipjack tuna) combined with the IOTC

364 management measure that was implemented to rebuild the stock of yellowfin tuna have

365 strongly modified the productivity and spatio-temporal patterns of the purse seine fishery with

366 recent effects on both catch and fuel consumption. Second, we estimated the past and current

367 levels of fuel consumption and GHG emissions of the Indian Ocean purse seine fishery over four

368 decades. We showed how emissions varied from the inception of the fishery to its evolution as

369 described by changes in the fleet structure (i.e., age and size of the vessels), technology, and

370 the effects of the environment on tuna catchability and management measures. The whole

371 fishery, including its support vessel component, annually consumed about $160,000 \mathrm{t}$ of fuel and

372 emitted about 590,000 t of $\mathrm{CO}_{2}$-eq GHG from 2015 to 2019. Finally, we demonstrated the

373 efficiency of the implementation of sulphur limits in the Indian Ocean purse seine fishery. These

374 limits resulted in the sharp reduction of the $\mathrm{SO}_{2}$ air pollution which had exceeded $1,500 \mathrm{t}$ in

3752015.

\section{GHG emissions}

377 Considering annual estimates of GHG emissions available from the literature, our results

378 indicate that the Indian Ocean purse seine fishery represented about $0.37 \%$ of the global

379 fisheries emissions in 2000 (Tyedmers et al., 2005), 0.24\% in 2011 (Parker et al., 2018) and

$380 \quad 0.32 \%$ in 2016 (Greer et al., 2019). Emissions from this highly industrial fishery are overall low

381 due to the small number of active vessels ( $\sim 50$ purse seiners) and despite their large size ( $\sim 90 \mathrm{~m}$

382 length overall) and the wide spatial extent of their fishing grounds. Tuna fisheries of the Indian

383 Ocean represented about $20 \%$ of the global tuna catch over the last decades (Taconet et

384 al. 2018). The importance of coastal fisheries has steadily increased over time and they now 
385 contribute to about $70 \%$ of the total tuna catch (Fiorellato et al. 2019). In this context, it seems

386 essential to extend such analysis to the other industrial components of the tuna fisheries

387 (i.e. longliners and pole and liners) but also to the thousands of small fishing vessels that target

388 tunas and other pelagic fishes with a large variety of fishing gears (e.g. handline, gillnets,

389 driftnets) to better assess the multiple sources of air pollution by fisheries across the Indian

390 Ocean.

\section{Purse seiners' characteristics and fuel consumption}

392 Vessel characteristics (e.g., hull design, propeller, auxiliary engine and cold storage capacity) as

393 well as fishing strategies and tactics affect the distance travelled and fuel consumption

394 (Guillotreau et al., 2011; Sala et al., 2011). Our results showed that size and age explain a

395 significant part of the differences observed in annual fuel consumption between vessels. Purse

396 seiners' length increased steadily over the last four decades. Some fishing companies invested

397 in very large boats $(>90 \mathrm{~m}$ ) throughout the 1990 s and 2000 s to reduce the fuel to catch ratio

398 and increase profit (Campling, 2012). Economic incentives explain the increasing size of purse

399 seiners to a large extent as the economies of scale are high for this highly capitalized industry

400 characterized by heavy fixed costs. Fuel costs represent on average $20 \%$ of the total operating

401 costs of a purse-seine vessel fishing in the Indian Ocean (Miyake et al., 2010). However, the

402 business model of purse seine fishing companies became more dependent on fuel price rises

403 during the oil crisis of 2008 when the energy costs reached more than $50 \%$ of the running costs

404 (Miyake et al., 2010). Even for smaller vessels such as Japanese longliners, fuel costs rose from

4057 up to $23 \%$ of total running costs between 1994 and 2006 (Miyake et al., 2010). When it is not

406 possible to implement a slow-steaming strategy, one way of dealing with such a dependency is 
407 to increase the size of vessels to reduce unit costs (Cariou, 2011). This strategy is only possible

408 because the environmental costs of carbon emission externalities are not included in oil price

409 (Lvovsky et al., 2000). Furthermore, government subsidies for vessel construction and tax

410 exemption of fuel consumption may have supported the development of larger vessels and

411 buffered the effects of increased oil price to some extent (Sumaila et al., 2008).

412 In recent years, several new purse seiners were built and equipped with diesel-electric

413 propulsion systems that optimize the use of energy according to power demand. As such, fuel

414 consumption and associated air pollutant emissions are reduced (Hideki et al., 2011).

415 Nevertheless, the adoption of these mixed systems was mainly driven by the development of

416 ultra-freezing capacities onboard these vessels to store part of the catch at temperatures

417 between $-40^{\circ} \mathrm{C}$ and $-60^{\circ} \mathrm{C}$ and target markets of higher value than canned tuna. The high power

418 required to maintain these cold storage conditions actually resulted in the increase of the

419 overall fuel consumption of the purse seine fleet. This was shown by the effect of construction

420 period in our model that indicated that vessels built in the 2010 s consume more than vessels

421 built throughout the 1990s-2000s.

\section{Fishing strategy and fuel consumption}

423 Fuel consumption varies with purse seine fishing strategy which depends on several factors

424 driven by resource availability, market demand and costs, and are affected by innovation and

425 technological changes (Guillotreau et al., 2011; Torres-Irineo et al., 2014). In particular, the

426 advent of satellite-tracked buoys equipped with accurate positioning systems in the early 2000s

427 supported the development of FAD-fishing that has become increasingly prevalent over the 
428 years (Fonteneau et al., 2013; Maufroy et al., 2015). The profitability of the very large purse

429 seiners (>90-100 $\mathrm{m}$ ) relied on an increasing number of GPS-tracked FADs and the association

430 with support vessels that manage the array of FADs, while smaller, less-costly purse seiners

$431(<80 \mathrm{~m})$ generally used less FADs and seasonally targeted FSCs of large yellowfin tuna

432 (Guillotreau et al., 2011; Maufroy et al., 2017). Since the early 2010s, buoys attached to the

433 FADs include acoustic units that provide real-time information on the biomass of tuna occurring

434 in the vicinity of the drifting rafts (Lopez et al., 2014). This has led to increasing fishing efficiency

435 and success and enables further FAD-fishing throughout the year (Wain et al., 2020). The

436 increasing use of FADs has substantially modified the spatial extent and movement patterns of

437 the purse seiners. These vessels spend less time searching for tuna and more time steaming

438 towards the FADs where fish appear to be present. This may explain that the fuel consumption

439 increased more on average for a FAD set than a FSC set in our model although this was a

440 marginal effect and was not significant considering the large variability between vessels and

441 years. It should be noted however that vessels targeting FAD-associated schools make more

442 sets per day than when fishing on FSCs (Floch et al., 2019). The FUI for purse seiners targeting

443 FADs would then increase through increased number of fishing sets and associated fuel

444 consumption but decrease through increased catch per set enabled by better selection of the

445 FADs (Wain et al., 2020).

446 At short time scales, fishing tactics depend on the technical skills and different sources of

447 information available to the skipper, e.g., location of oceanographic features and acoustic

448 estimates of tuna abundance around GPS-tracked FADs (Baidai et al., 2020; Gaertner et al., 449 1999). In addition, cooperative fishing is an essential component of purse seine fishing as FAD 
450 position information can be shared between vessels and some skippers work in groups

451 (Lennert-Cody et al., 2020; Snouck-Hurgronje et al., 2018). Cooperative behaviour may

452 significantly reduce searching time and associated fuel costs, and this could explain the non-

453 linear pattern observed for the number of FSC sets in our model, i.e., the initial reduction in fuel

454 consumed when the number of FSCs increased from 0 to 60 . The transfer of information on

455 tuna presence between vessels explains the spatio-temporal co-occurrence of several purse

456 seiners in the same fishing area observed. For instance, this has been observed in the cases

457 where there are large concentrations of tuna and all purse seiners were found in the same

458 concentrated fishing grounds (Fonteneau et al., 2008). Further work is required to study how

459 collaborative fishing may affect fishing success, the relationship between fuel consumption and

460 catch measured by the FUI and more generally the use of purse seine catch rates as indices of

461 tuna abundance (Lennert-Cody et al., 2020).

\section{Emissions's variability}

463 GHG emissions of the Indian Ocean purse seine fishery showed a general increasing trend over

464 the last four decades described by some strong interannual variability and a mean annual value

465 of 590,000 t of $\mathrm{CO}_{2}$-eq from 2015 to 2019 . Our estimates are conservative as they do not

466 include emissions from support vessels prior to 2013 nor from purse seiners that operated in

467 the northwest and eastern parts of the Indian Ocean. Information on vessels' characteristics

468 and fishing operations for these vessels was not available for the present study. However, we

469 assume that their contribution to the total air pollutant emissions of the Indian Ocean purse

470 seine fishery is on the order of magnitude of their catch, i.e., less than $6 \%$ of the total purse

471 seine catch for the whole period. Support vessels appeared in the late 1980 s in the purse seine 
472 fishery but their role has increased since the late 1990s. Their number varied between 10 and

47315 over 1997 to 2012 (Chassot et al., 2015), and likely would represent an additional 3-4\% of

474 the total fuel consumed by purse seiners' activity during that period.

475 Our results showed that fuel consumption and associated emissions varied strongly over time

476 as a result of several intricate factors, including changes in fleet characteristics and strategy,

477 changes in accessibility to fishing grounds and tuna abundance and catchability. In the Indian

478 Ocean, annual catch rates are strongly related to the extent of favourable feeding habitats for

479 tuna, i.e., good environmental conditions result in fishery contraction (Druon et al., 2017).

480 Although the reduction in the size of fishing grounds, supported by collaborative fishing, might

481 suggest a reduction in fuel consumption, we found that increased catchability may actually

482 result in increased numbers of fishing sets and eventually higher fuel consumption. In

483 particular, the period 2003 to 2005 was characterized by an exceptional abundance of mantis

484 shrimp Natosquilla investigatoris, a major prey of tuna that occurred in large swarms near the

485 surface and substantially increased the catchability of tuna schools (Potier et al., 2007;

486 Romanov et al., 2015). During that period, the total landings of the fishery were larger than

487385,000 t per year. GHG emissions showed a major increase and reached almost 500,000 $t$ of

$488 \mathrm{CO}_{2}$-eq per year. Our study also showed that GHG emissions declined by 30\% over 2009 to 2011

489 due to the piracy threat, which resulted in a major decline of overall purse seine effort and

490 reduction in the extent of the fishing grounds (Chassot et al., 2012). Although too early to

491 assess, preliminary information suggests a major decrease in purse seiners' effort and GHG

492 emissions in 2020 in relation with the COVID-19 pandemic, possibly of the same magnitude as

493 observed during the main period of the Somali piracy threat. 


\section{Energetic and environmental performance}

495 FUl is used to describe and compare the environmental performance of fisheries and fishing

496 gears in terms of output and efficiency (Parker et al., 2018; R. W. R. Parker, Vázquez-Rowe, et

497 al., 2015). Based on a global survey among purse seine fishing companies, Tyedmers and Parker

498 (2012) found that the FUI of the purse seine fishery in 2009 was lower in the Indian Ocean (454

$\left.499 \mathrm{It}^{-1}\right)$ than in the Atlantic $\left(513 \mathrm{It}^{-1}\right)$ but higher than in the Pacific Ocean $\left(354 \mathrm{I} \mathrm{t}^{-1}\right)$. Our mean FUI

500 predictions of $496 \mathrm{It}^{-1}$ in 2009 are slightly higher than their estimate, possibly due to the

501 difference in methodology and sample size (i.e., nine purse seiners in the sample of Tyedmers

502 and Parker (2012) and 46 in this study). The review of historical values of FUI in purse seine

503 fisheries shows a range of $200-2,500 \mathrm{It}^{-1}$ and a more restricted range (200-527 I t $\left.\mathrm{t}^{-1}\right)$ since 2000

504 (R. W. R. Parker, Hartmann, et al., 2015). Our results showed that the mean annual FUI of the

505 Indian Ocean purse seine fishery exceeded this range in the last decade, reaching more than

$506650 \mathrm{It}^{-1}$ in 2015 , while the same fleet showed a FUI of less than $420 \mathrm{I} \mathrm{t}^{-1}$ in 2018 . This illustrates

507 the large temporal variability in FUI linked to the main factors described above (see Fishing

508 strategy and fuel consumption). In this context, developing and implementing routine

509 monitoring of fuel consumption using standardized methods is required to provide more

510 accurate assessment of fisheries energetic performance.

511 The economic drivers and consequences of the FUI were beyond the scope of this study.

512 Nonetheless, it would be interesting in future research to look at the impact of heavy fuel oil

513 and marine diesel oil prices on fishing strategies, fuel consumption and the level of emissions.

514 In particular, if the fishing companies were deemed sensitive to price signals, incentive-based

515 policies such as tax instruments could be implemented as complements to the new standards 
516 of sulphur content, at least for catches taking place within the exclusive economic zones of

517 coastal countries.

518 Air pollutant emissions from fuel combustion constitute one component of the environmental

519 performance of a fishery. The status of the stocks that are targeted as well as the impact of

520 fishing on habitat and species that are taken as bycatch should also be scrutinised when it

521 comes to assessing the sustainability of a fishery as is done for eco-labels such as the Marine

522 Stewardship Council (MSC) fisheries standard. In recent years, most purse seine fisheries have

523 entered into the process of MSC certification through Fishery Improvement Projects (Crona et

524 al., 2019) which do not include any constraint related to emissions of air pollutants. Quantifying

525 the magnitude and composition of air pollutant emissions should be an integral component to

526 monitoring sustainability of fisheries.

\section{Conclusion}

528 Our model of purse seiner fuel consumption allowed us to reconstruct the history of air

529 pollutant emissions of the Indian Ocean purse seine fishery over four decades. The FUI

530 predicted by our model is in line with that found in earlier studies, but it also shows a great

531 inter-annual variability according to environmental and fishing conditions that should be taken

532 into greater consideration. The shifting structure of the fleet towards larger vessels assisted by

533 support vessels and more intensive use of FADs tend to increase fuel consumption, hence air

534 pollution in the fishery. GHGs now reach some 600,000 t of $\mathrm{CO}_{2}$-eq yearly. This high level of air

535 pollutant emissions should certainly be a concern to the eco-label schemes promoting 
536 sustainable fisheries, responding to the Sustainable Development Goal \#14 of the United

537 Nations.

538 Further work is required to better account for the additional air pollution linked to the global

539 tuna supply chain: transportation of raw tuna material to the processing factories located all

540 over the world and of processed tuna products to the consumer markets that are dominated by

541 the EU and the USA (Miyake et al., 2010). The model will also be useful to predict the expected

542 effects of changes in fleet capacity and fishing activities on the Seychelles national economy,

543 e.g., to quantify the decrease in revenues for the government linked to the stop of vessels due

544 to the COVID-19 pandemic.

545 Acknowledgments. We are grateful to all the people involved in the collection and

546 management of the fisheries data used in the present study, including the purse seine fishing

547 associations ANABAC, OPAGAC and ORTHONGEL. Special thanks to Patrice Dewals for his

548 dedication to the curation of the fisheries data. We are deeply grateful to Joan Didon for her

549 work on the bunkering data as well as Sarah Romain, Xerxes Pardiwalla and Alexandre Barbier

550 from SEYPEC for their support and assistance with the fuel data set. Special thanks to Julien

551 Barde, Emmanuel Blondel \& Paul Taconet for their help with global tuna fisheries data and Dan

552 Fu for statistical advice. The collection of the fisheries data was co-funded by the Seychelles

553 government and the EU Data Collection Framework (EC 665/2008 and 199/2008). PG

554 acknowledges the financial support of the French national Research Agency program CIGOEF

555 (ANR-17-CE32-0008). We are finally grateful to Dr. Anne-Elise Nieblas for editing the manuscript

556 and two anonymous referees who greatly helped improving the article. 
557 Table 1: Description of the fuel data set. Number of vessels and bunkering operations with 558 mean, maximum and total weight ( $t$ ) of fuel delivered annually to the purse seiners (PS) and 559 support vessels (SV) that called on Port Victoria, Seychelles, during 2013-2019.

\begin{tabular}{rrrrrrr}
\hline Year & VesselType & Vessels & Operations & MeanWeight & MaxWeight & TotalWeight \\
\hline 2013 & PS & 38 & 390 & 269 & 858 & 104,731 \\
2013 & SV & 10 & 50 & 72 & 151 & 3,613 \\
2014 & PS & 42 & 465 & 260 & 672 & 120,883 \\
2014 & SV & 15 & 68 & 81 & 135 & 5,526 \\
2015 & PS & 49 & 534 & 279 & 792 & 149,043 \\
2015 & SV & 18 & 96 & 84 & 176 & 8,099 \\
2016 & PS & 47 & 606 & 274 & 777 & 166,227 \\
2016 & SV & 21 & 120 & 84 & 176 & 10,103 \\
2017 & PS & 45 & 557 & 263 & 713 & 146,588 \\
2017 & SV & 20 & 135 & 79 & 166 & 10,611 \\
2018 & PS & 44 & 580 & 247 & 729 & 143,095 \\
2018 & SV & 18 & 121 & 74 & 152 & 8,932 \\
2019 & PS & 45 & 544 & 261 & 605 & 141,735 \\
2019 & SV & 16 & 113 & 79 & 172 & 8,889 \\
\hline
\end{tabular}

560 


\section{Tables}

562 Table 2: Description of the fisheries data set selected for modelling fuel consumption. Number

563 of vessels ( $N$ ) and mean annual values of length overall (LOA; $m$ ), fishing effort (days at sea),

564 numbers of sets on schools associated with fish aggregating devices (SetsFAD) and on free

565 swimming schools (SetsFSC), landings $(t)$ and fuel consumed $(t)$ for the purse seiners that

566 called exclusively on Port Victoria, Seychelles, during 2013-2019.

\begin{tabular}{rrrrrrrr}
\hline Year & N & LOA & \multicolumn{1}{c}{ DaysAtSea } & SetsFAD & SetsFSC & Landings & Fuel \\
\hline 2013 & 8 & 94.1 & 298 & 254 & 63 & 11,463 & 3,989 \\
2014 & 19 & 89.6 & 300 & 205 & 52 & 7,593 & 3,568 \\
2015 & 23 & 90.9 & 267 & 170 & 72 & 6,672 & 3,465 \\
2016 & 31 & 88.8 & 300 & 228 & 61 & 7,207 & 3,605 \\
2017 & 29 & 92.7 & 270 & 231 & 66 & 8,283 & 3,499 \\
2018 & 30 & 91.5 & 258 & 259 & 14 & 11,064 & 3,494 \\
2019 & 28 & 89.8 & 245 & 219 & 41 & 8,384 & 3,014 \\
\hline
\end{tabular}


568 Table 3: Analysis of variance outputs for the annual quantity of fuel consumed ( $t$ ) by large569 scale purse seiners. YOC = Year of construction; SetsFAD = number of sets on schools 570 associated with fish aggregating devices; $L O A=$ Length overall; SetsFSC = number of sets on 571 free swimming schools; $s=$ smooth function; edf = effective degrees of freedom; $F=$ Test 572 statistic.

\begin{tabular}{lcrc}
\hline Source of variation & edf & F value & p-value \\
\hline DecadeYOC & 2.00 & 22.2 & $<0.001$ \\
SetsFAD & 1.00 & 36.2 & $<0.001$ \\
s(LOA) & 8.64 & 32.1 & $<0.001$ \\
s(DaysAtSea) & 4.94 & 22.4 & $<0.001$ \\
s(SetsFSC) & 2.58 & 5.2 & 0.0014 \\
\hline
\end{tabular}


$574 \quad$ Figures
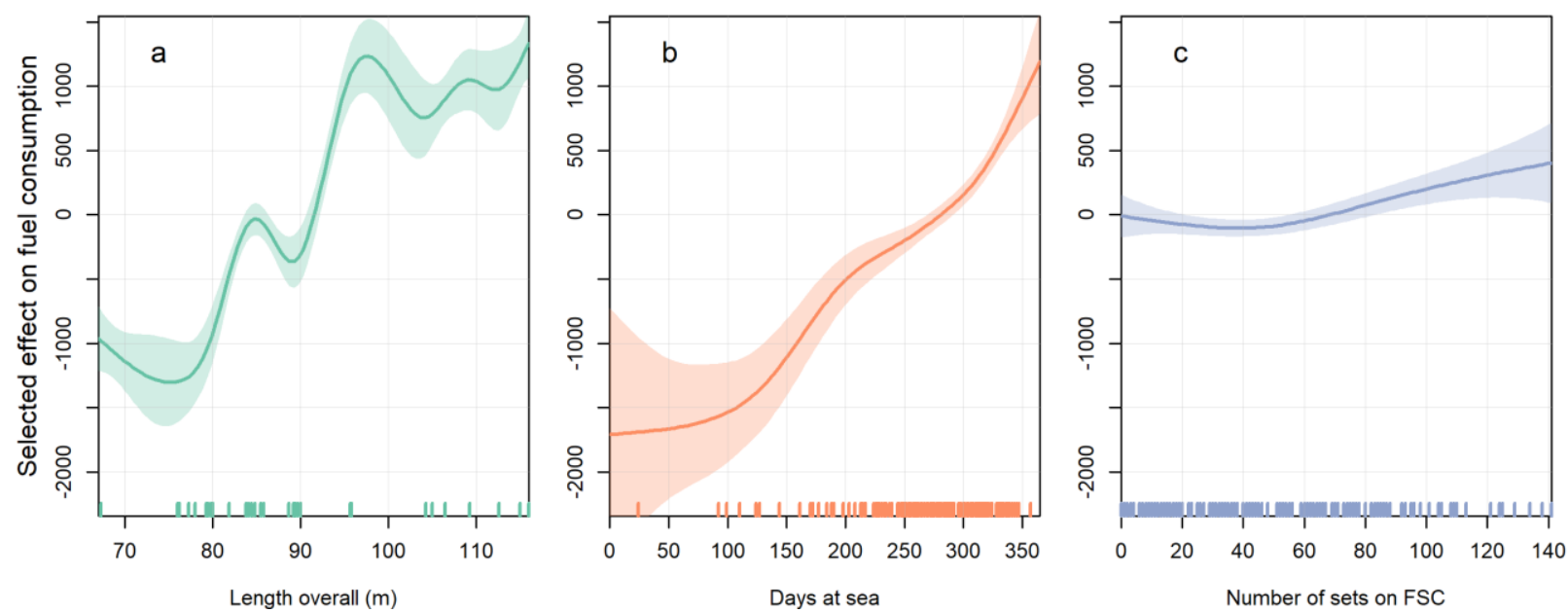

576 Figure 1: Variability in annual fuel consumption of large-scale purse seiners operating in the 577 western Indian Ocean. Predictions for the three continuous variables included in the model of 578 annual fuel consumption: (a) length overall ( $m$ ), (b) days a sea, (c) number of sets on tuna 579 free-swimming schools (FSC).

580 


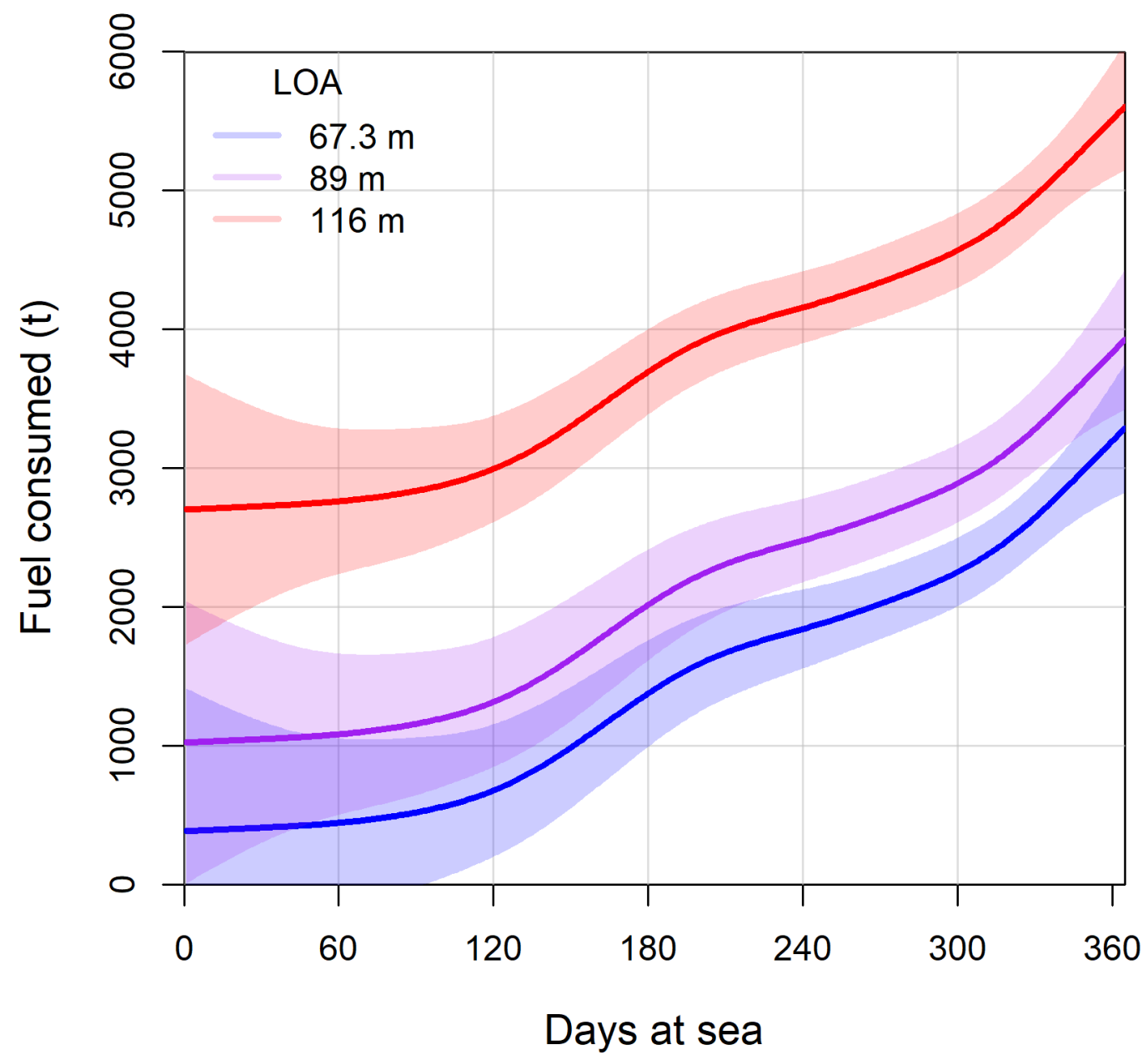

Figure 2: Effect of fishing effort and vessel length on fuel consumption of large-scale purse 583 seiners of the Indian Ocean. Predictions of quantity of fuel consumed $(t)$ by purse seiners of 584 different length overall $(\mathrm{LOA} ; \mathrm{m})$ as a function of the annual number of days spent at sea. 585 Solid lines are the mean predictions with 95\% confidence intervals for the smallest (67.3 $\mathrm{m}$ ), 586 medium-sized $(89.7 \mathrm{~m})$ and largest $(116 \mathrm{~m})$ vessels of the purse seine fishery. 


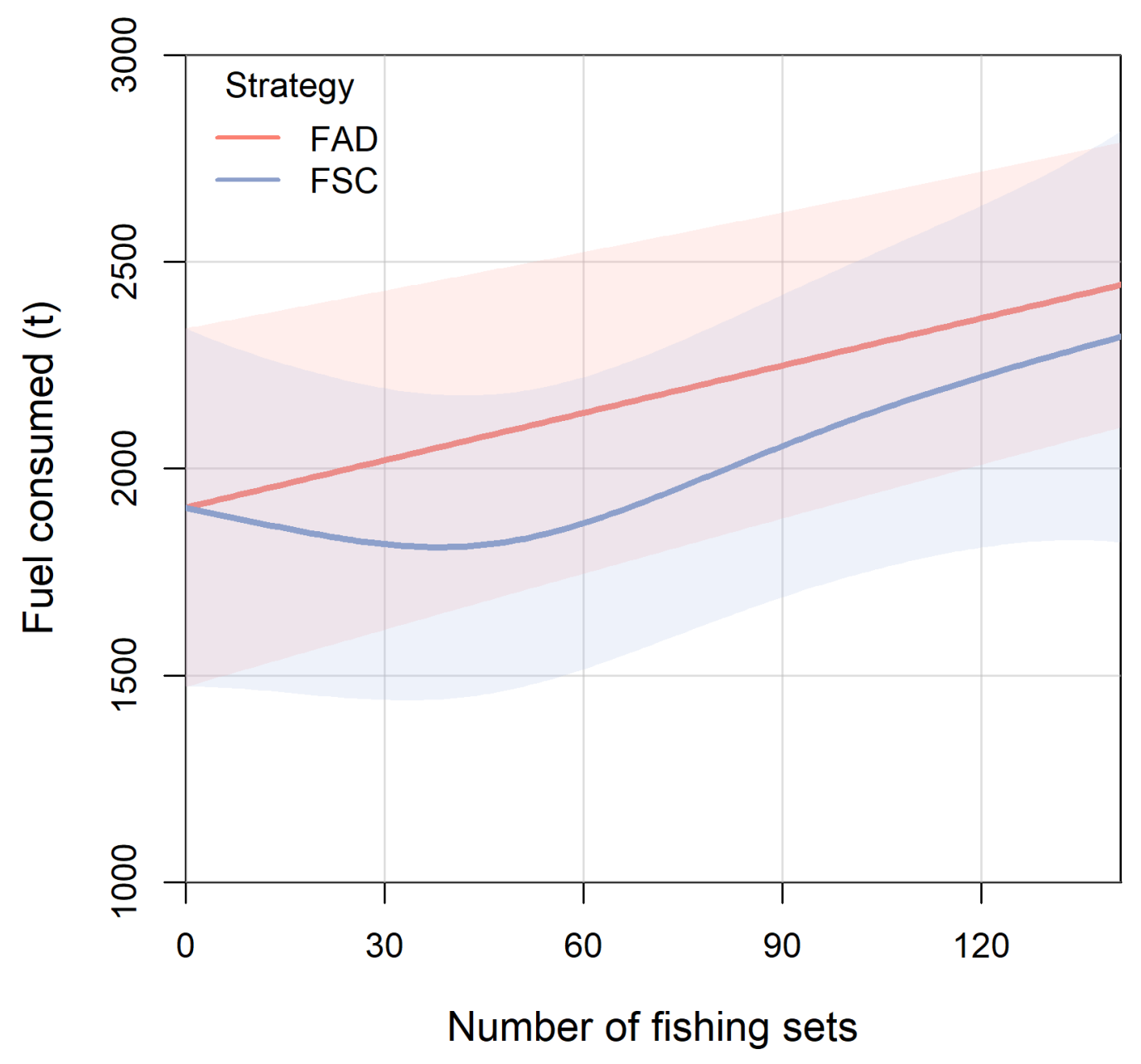

Figure 3: Effect of fishing strategy on fuel consumption of large-scale purse seiners of the 590 Indian Ocean. Predictions of quantity of fuel consumed $(t)$ by a medium-sized purse seiner 591 (89.7 m) as a function of the annual number of fishing sets that would have been made 592 exclusively on schools associated with fish aggregating devices (FADs) or on free-swimming 593 schools (FSCs). Solid lines are the mean predictions with 95\% confidence intervals. 


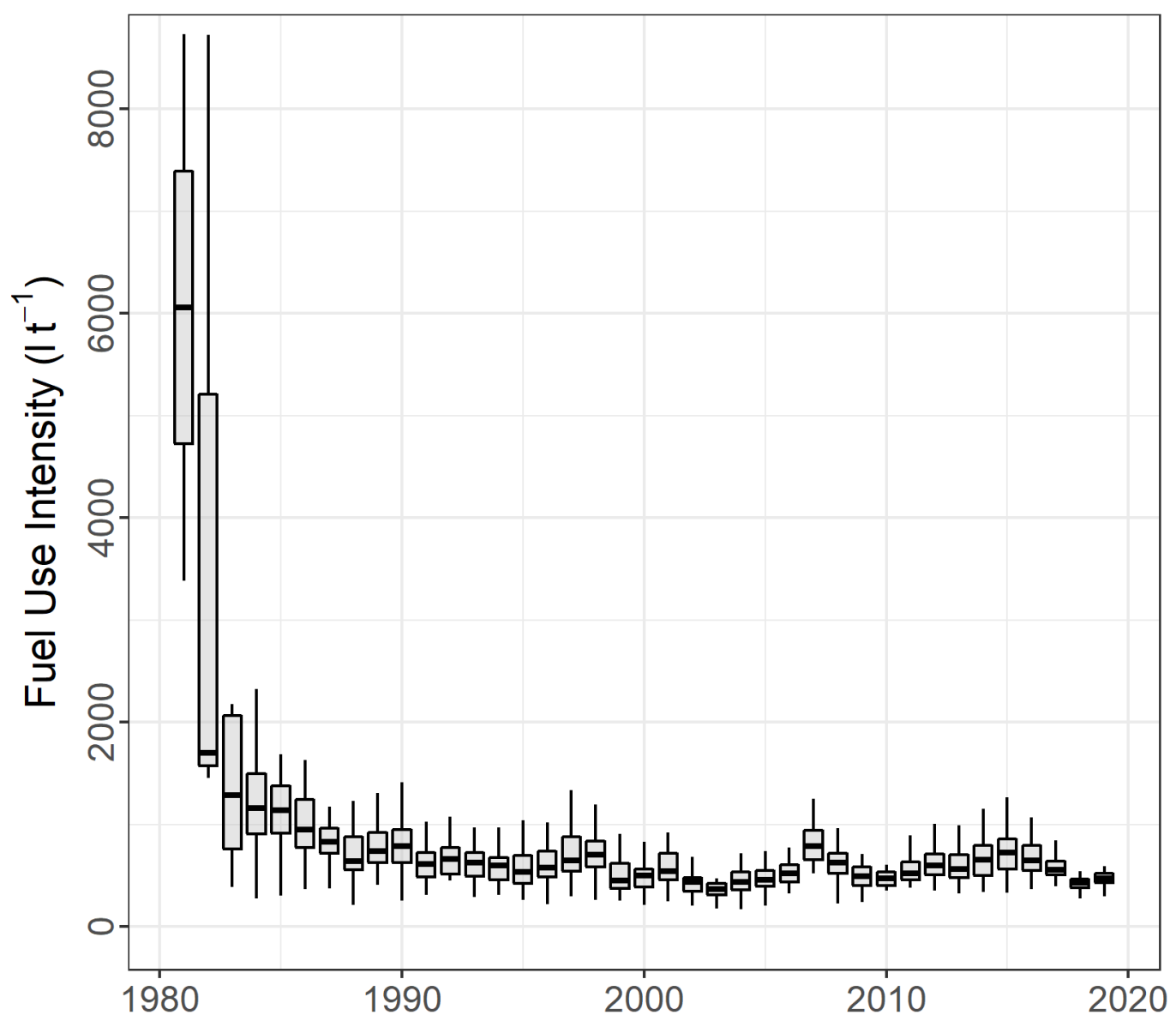

595

596 Figure 4: Temporal variability in environmental performance of the Indian Ocean purse seine 597 fishery from 1981 to 2019 as described by the annual distribution of Fuel Use Intensity $\left(1 t^{-1}\right)$. 

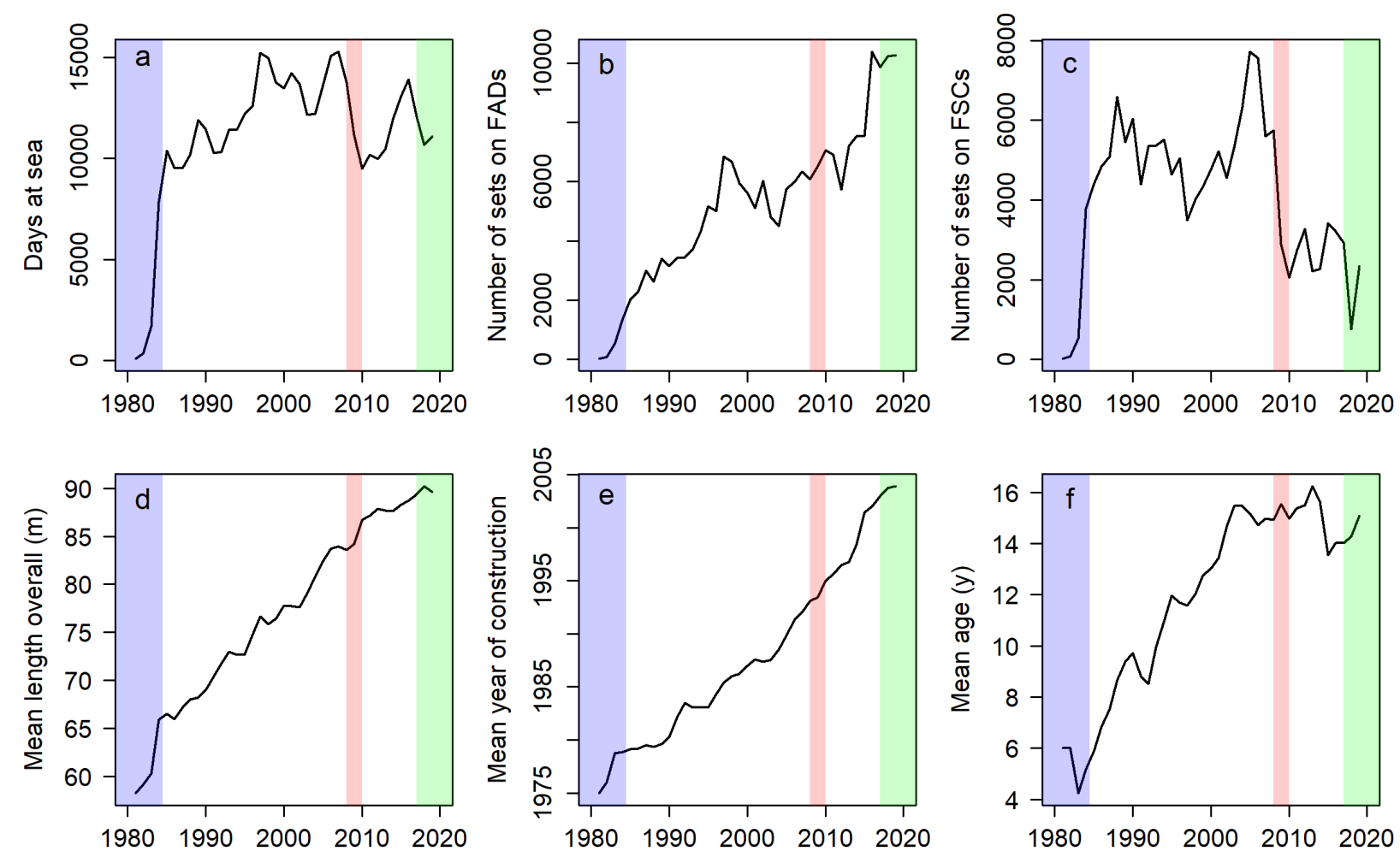

600 Figure 5: Annual changes in fishing effort, activities, and main technical characteristics of the 601 western Indian Ocean purse seine fishery from 1981 to 2019. Annual time series of (a) days at 602 sea, (b) number of sets on tuna schools associated with Fish Aggregating Devices (FADs), (c) 603 number of sets on free swimming schools (FSCs), (d) mean length overall $(\mathrm{m}),(\mathrm{e})$ mean year 604 of construction and (f) mean age of the purse seiners that operated in the western Indian 605 Ocean during 1981-2019. Blue polygon = Onset of the fishery; Red polygon = Piracy threat and 606 worldwide financial crisis; Green polygon = Yellowfin tuna catch limit. 

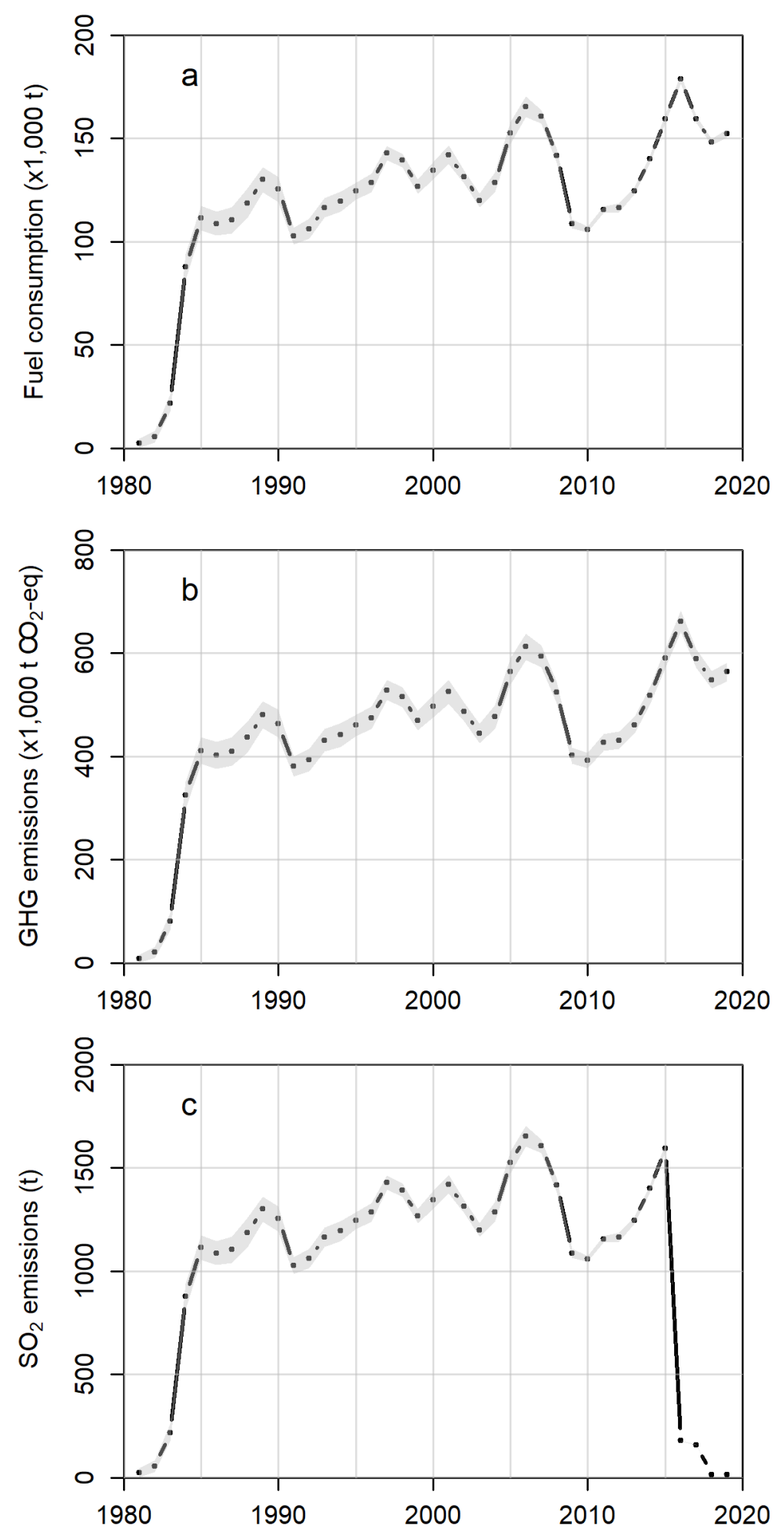

609 Figure 6: Temporal variability in fuel consumption, greenhouse gas and sulphur dioxide 610 emissions of the western Indian Ocean purse seine fishery from 1981 to 2019. Annual time 611 series of (a) fuel consumption ( $t$ ), (b) GHG emissions (x1,000 t $\mathrm{CO}_{2}$-eq) and (b) $\mathrm{SO}_{2}$ emissions 
612 ( $t$ ) as derived from model predictions of fuel annually consumed by the fleet of purse seiners 613 and support vessels based in Port Victoria, Seychelles, during 1981-2019.

614 


\section{References}

616 Assan, C., Lucas, J., Augustin, E., Delgado de Molina, A., Maufroy, A., Chassot, E., 2015.

617 Seychelles auxiliary vessels in support of purse seine fishing in the Indian Ocean during

618 2005-2014, in: IOTC Proceedings. IOTC, Montpellier, France, 23-28 October 2015, p. 12.

619 Assan, C., Lucas, J., Chassot, E., 2019. Statistics of the Seychelles purse seine fleet targeting 620 tropical tunas in the Indian Ocean (2000-2018), in: IOTC Proceedings. IOTC, San Sebastian, 621 Spain, 21-26 October 2019, p. 18p.

622 Baez, J.-C., Fernandez, F., Pascual Alayon, P.J., Ramos, M.L., Deniz, S., Abascal, F., 2018.

623 Updating the statistics of the EU-Spain purse seine fleet in the Indian Ocean (1990-2017),

624 in: IOTC Proceedings. IOTC, Victoria Mahé, 29 October - 3 November 2018, p. 34.

625 Bagoulla, C., Guillotreau, P., 2020. Maritime transport in the French economy and its impact 626 on air pollution: An input-output analysis. Marine Policy 116, 103818.

627 https://doi.org/10.1016/j.marpol.2020.103818

628 Baidai, Y., Dagorn, L., Amande, M.J., Gaertner, D., Capello, M., 2020. Machine learning for 629 characterizing tropical tuna aggregations under Drifting Fish Aggregating Devices (DFADs) 630 from commercial echosounder buoys data. Fisheries Research 229, 105613.

631 https://doi.org/10.1016/j.fishres.2020.105613

632 Campling, L., 2012. The tuna "commodity frontier": Business strategies and environment in 633 the industrial tuna fisheries of the western Indian Ocean. Journal of Agrarian Change 12, 634 252-278. https://doi.org/10.1111/j.1471-0366.2011.00354.x

635 Cariou, P., 2011. Is slow steaming a sustainable means of reducing CO2 emissions from 636 container shipping? Transportation Research Part D: Transport and Environment 16, 260637 264. https://doi.org/10.1016/j.trd.2010.12.005

638 Chassot, E., Assan, C., Soto, M., Damiano, A., Delgado de Molina, A., Joachim, L.D., Cauquil, P., 639 Lesperance, F., Curpen, M., Lucas, J., Floch, L., 2015. Statistics of the European Union and 640 associated flags purse seine fishing fleet targeting tropical tunas in the Indian Ocean 1981641 2014, in: IOTC Proceedings. IOTC, Montpellier, France, 23-28 October 2015, p. 31p.

642 Chassot, E., Guillotreau, P., Kaplan, D.M., Vallée, T., 2012. Piracy and tuna fisheries, in: Piracy 643 in Comparative Perspective: Problems, Strategies, Law. Editions A. Pedone \& Hart 644 Publishing.

645 Chu Van, T., Ramirez, J., Rainey, T., Ristovski, Z., Brown, R.J., 2019. Global impacts of recent 646 IMO regulations on marine fuel oil refining processes and ship emissions. Transportation 647 Research Part D: Transport and Environment 70, 123-134.

648 https://doi.org/10.1016/j.trd.2019.04.001

649 Corbett, J.J., Fischbeck, P., 1997. Emissions from ships. Science 278, 823-824.

650 https://doi.org/10.1126/science.278.5339.823 
651 Corbett, J.J., Fischbeck, P.S., Pandis, S.N., 1999. Global nitrogen and sulfur inventories for 652 oceangoing ships. Journal of Geophysical Research: Atmospheres 104, 3457-3470.

653 https://doi.org/10.1029/1998JD100040

654 Corbett, J.J., Winebrake, J.J., Green, E.H., Kasibhatla, P., Eyring, V., Lauer, A., 2007. Mortality 655 from ship emissions: A global assessment. Environmental Science \& Technology 41, 8512656 8518. https://doi.org/10.1021/es071686z

657 Crona, B., Käll, S., Holt, T.V., 2019. Fishery Improvement Projects as a governance tool for 658 fisheries sustainability: A global comparative analysis. PLOS ONE 14, e0223054.

659 https://doi.org/10.1371/journal.pone.0223054

660 Dalsøren, S.B., Eide, M.S., Endresen, Ø., Mjelde, A., Gravir, G., Isaksen, I.S.A., 2009. Update on 661 emissions and environmental impacts from the international fleet of ships: The 662 contribution from major ship types and ports. Atmospheric Chemistry and Physics 9, 2171663 2194. https://doi.org/https://doi.org/10.5194/acp-9-2171-2009

664 Druon, J.-N., Chassot, E., Murua, H., Lopez, J., 2017. Skipjack tuna availability for purse seine 665 fisheries is driven by suitable feeding habitat dynamics in the Atlantic and Indian Oceans. 666 Frontiers in Marine Science 4. https://doi.org/10.3389/fmars.2017.00315

667 FAO, 2018. The state of world fisheries and aquaculture 2018 - Meeting the sustainable 668 development goal. FAO fisheries; Aquaculture Department, Rome, Italy.

669 FAO, 1997. Fisheries management (FAO Technical Guidelines for Responsible Fisheries No. 670 4). FAO, Rome, Italy.

671 Fiorellato, F., Pierre, L., Geehan, J., 2019. Review of the statistical data and fishery trends for 672 tropical tunas, in: IOTC Proceedings. IOTC, Donostia-San Sebastian, Spain, 21-26 October 6732019, p. 57.

674 Floch, L., Depetris, M., Dewals, P., Duparc, A., Kaplan, D.M., Lebranchu, J., Marsac, F., Pernak, 675 F., Bach, P., 2019. Statistics of the French purse seine fishing fleet targeting tropical tunas in 676 the Indian Ocean (1981-2018), in: IOTC Proceedings. IOTC, San Sebastian, Spain, 21-26 677 October 2019, p. 27.

678 Fonteneau, A., 2010. Atlas des pêcheries thonières de l'Océan Indien = Atlas of Indian Ocean 679 tuna fisheries. IRD.

680 Fonteneau, A., Chassot, E., Bodin, N., 2013. Global spatio-temporal patterns in tropical tuna 681 purse seine fisheries on drifting fish aggregating devices (DFADs): Taking a historical 682 perspective to inform current challenges. Aquatic Living Resources 26, 37-48.

683 https://doi.org/10.1051/alr/2013046

684 Fonteneau, A., Lucas, V., Tewkai, E., Delgado, A., Demarcq, H., 2008. Mesoscale exploitation 685 of a major tuna concentration in the Indian Ocean. Aquatic Living Resources 21, 109-121.

686 https://doi.org/10.1051/alr:2008028 
687 Gaertner, D., Pagavino, M., Marcano, J., 1999. Influence of fishers' behaviour on the 688 catchability of surface tuna schools in the Venezuelan purse-seiner fishery in the Caribbean Sea. Canadian Journal of Fisheries and Aquatic Sciences 56, 394-406.

690 https://doi.org/10.1139/f98-191

691 Greer, K., Zeller, D., Woroniak, J., Coulter, A., Winchester, M., Palomares, M.L.D., Pauly, D., 692 2019. Global trends in carbon dioxide (CO2) emissions from fuel combustion in marine 693 fisheries from 1950 to 2016. Marine Policy 107, 103382.

694 https://doi.org/10.1016/j.marpol.2018.12.001

695 Guillotreau, P., Salladarré, F., Dewals, P., Dagorn, L., 2011. Fishing tuna around Fish 696 Aggregating Devices (FADs) vs free swimming schools: Skipper decision and other 697 determining factors. Fisheries Research 109, 234-242.

698 https://doi.org/16/j.fishres.2011.02.007

699 Hastie, T., Tibshirani, R., 1990. Generalized Additive Models. Chapman \& Hall, London, UK.

700 Hideki, Y., Hiroaki, M., Aiichiro, S., 2011. Energy saving technology of the diesel-electric 701 propulsion system for Japanese coastal vessels. IHI Engineering Review 44, 12-16.

702 Holloway, S., Karimjee, A., Akai, M., Pipatti, R., Rypdal, K., 2006. IPCC Guidelines for National 703

704

705 Greenhouse Gas Inventories, Volume 2: Energy, Chapter 5: Carbon Dioxide Transport, Injection, and Geological Storage, Intergovernmental Panel on Climate Change (IPCC). Accessed on July 25, 2012.

706

Hospido, A., Tyedmers, P., 2005. Life cycle environmental impacts of Spanish tuna fisheries. Fisheries Research 76, 174-186. https://doi.org/10.1016/j.fishres.2005.05.016

Hospido, A., Vazquez, M.E., Cuevas, A., Feijoo, G., Moreira, M.T., 2006. Environmental assessment of canned tuna manufacture with a life-cycle perspective. Resources, Conservation and Recycling 47, 56-72. https://doi.org/10.1016/j.resconrec.2005.10.003

711 Jägerbrand, A.K., Brutemark, A., Barthel Svedén, J., Gren, I.-M., 2019. A review on the 712 environmental impacts of shipping on aquatic and nearshore ecosystems. Science of The

713 Total Environment 695, 133637. https://doi.org/10.1016/j.scitotenv.2019.133637

714 Justel-Rubio, A., Recio, L., 2020. A snapshot of the large-scale tropical tuna purse seine 715 fishing fleets as of June 2020 (ISSF Technical Report No. 2020-14). International Seafood 716 Sustainability Foundation, Washington D.C., U.S.A.

717 Kawol, D., Sooklall, T., Shung, C.L., 2019. Analysis of catch and effort data of tropical tuna 718 from purse seine and longline fishery in Mauritius (2014-2018), in: IOTC Proceedings. 719 IOTC, San Sebastian, Spain, 21-26 October 2019, p. 13.

720 Lennert-Cody, C.E., Maunder, M.N., Román, M.H., Xu, H., Minami, M., Lopez, J., 2020. Cluster 721 analysis methods applied to daily vessel location data to identify cooperative fishing among tuna purse-seiners. Environmental and Ecological Statistics.

723 https://doi.org/10.1007/s10651-020-00451-7 
Lopez, J., Moreno, G., Sancristobal, I., Murua, J., 2014. Evolution and current state of the technology of echo-sounder buoys used by Spanish tropical tuna purse seiners in the Atlantic, Indian and Pacific Oceans. Fisheries Research 155, 127-137. https://doi.org/10.1016/j.fishres.2014.02.033

Lvovsky, K., Hughes, G., Maddison, D., Ostro, B., Pearce, D., 2000. Environmental costs of fossil fuels: A rapid assessment method with application to six cities.

730 Maufroy, A., Chassot, E., Joo, R., Kaplan, D.M., 2015. Large-scale examination of spatiotemporal patterns of drifting Fish Aggregating Devices (dFADs) from tropical tuna fisheries of the Indian and Atlantic Oceans. PLOS ONE 10, e0128023. https://doi.org/10.1371/journal.pone.0128023

Maufroy, A., Kaplan, D.M., Bez, N., Molina, D., Delgado, A., Murua, H., Floch, L., Chassot, E., 2017. Massive increase in the use of drifting Fish Aggregating Devices (dFADs) by tropical tuna purse seine fisheries in the Atlantic and Indian oceans. ICES Journal of Marine Science 74, 215-225. https://doi.org/10.1093/icesjms/fsw175

Miyake, M.P., Guillotreau, P., Sun, C.-H., Ishimura, G., others, 2010. Recent developments in the tuna industry: Stocks, fisheries, management, processing, trade and markets. FAO

740 Fisheries and Aquaculture Technical Paper 543, 125.

741 Parker, R.W.R., Blanchard, J.L., Gardner, C., Green, B.S., Hartmann, K., Tyedmers, P.H., Watson, R.A., 2018. Fuel use and greenhouse gas emissions of world fisheries. Nature Climate Change 8, 333-337. https://doi.org/10.1038/s41558-018-0117-x and economic dimensions of fuel use in Australian fisheries. Journal of Cleaner Production 87, 78-86. https://doi.org/10.1016/j.jclepro.2014.09.081

747 Parker, R.W.R., Tyedmers, P.H., 2015. Fuel consumption of global fishing fleets: Current 748 understanding and knowledge gaps. Fish and Fisheries 16, 684-696.

749 https://doi.org/10.1111/faf.12087

750 Parker, R.W.R., Vázquez-Rowe, I., Tyedmers, P.H., 2015. Fuel performance and carbon 751 footprint of the global purse seine tuna fleet. Journal of Cleaner Production, Carbon Emissions Reduction: Policies, Technologies, Monitoring, Assessment and Modeling 103, 753 517-524. https://doi.org/10.1016/j.jclepro.2014.05.017

754 Potier, M., Marsac, F., Cherel, Y., Lucas, V., Sabatié, R., Maury, O., Ménard, F., 2007. Forage 755 fauna in the diet of three large pelagic fishes (lancetfish, swordfish and yellowfin tuna) in the western equatorial Indian Ocean. Fisheries Research 83, 60-72. https://doi.org/10.1016/j.fishres.2006.08.020 supply vessel's logbooks implemented by the Spanish fleet and associated in Indian Ocean, in: IOTC Proceedings. IOTC, Victoria, Seychelles, 18-25 October 2010, p. 13. 
Romanov, E.V., Potier, M., Anderson, R.C., Quod, J.-P., Ménard, F., Sattar, S.A., Hogarth, P., 2015. Stranding and mortality of pelagic crustaceans in the western Indian Ocean. Journal of the Marine Biological Association of the United Kingdom. fishing fleets and the response of fished resources. Proceedings of the National Academy of Sciences 201820344. https://doi.org/10.1073/pnas.1820344116

Sala, A., De Carlo, F., Buglioni, G., Lucchetti, A., 2011. Energy performance evaluation of fishing vessels by fuel mass flow measuring system. Ocean Engineering 38, 804-809.

Snouck-Hurgronje, J.E., Kaplan, D.M., Chassot, E., Maufroy, A., Gaertner, D., 2018. Fishing on floating objects (FOBs): How French tropical tuna purse seiners split fishing effort between GPS-monitored and unmonitored FOBs. Canadian Journal of Fisheries and Aquatic Sciences 75, 1849-1858. https://doi.org/10.1139/cjfas-2017-0152

Sumaila, U.R., Teh, L., Watson, R., Tyedmers, P., Pauly, D., 2008. Fuel price increase, subsidies, overcapacity, and resource sustainability. ICES Journal of Marine Science 65, 832-840. https://doi.org/10.1093/icesjms/fsn070

Taconet, P., Chassot, E., Barde, J., 2018. Global monthly catch of tuna, tuna-like and shark species (1950-2015) aggregated by $1^{\circ}$ or $5^{\circ}$ squares (IRD level 2) (Version 1 ). Zenodo. Environment 74, 320-325. https://doi.org/10.1016/j.atmosenv.2013.04.014 and fishing strategies driven by new technologies: The case of tropical tuna purse seiners in the eastern Atlantic Ocean. Fisheries Research 155, 10-19. https://doi.org/10.1016/j.fishres.2014.02.017 global tuna fisheries: A preliminary assessment (No. ISSF Technical Report 2012-03). International Seafood Sustainability Foundation, McLean, Virginia, USA. efficiency due to the use of drifting FADs equipped with echosounders in tropical tuna purse seine fisheries. ICES Journal of Marine Science.

https://doi.org/10.1093/icesjms/fsaa216 
799 Winebrake, J.J., Corbett, J.J., Meyer, P.E., 2007. Energy use and emissions from marine 800 vessels: A total fuel life cycle approach. Journal of the Air \& Waste Management Association 801 57, 102-110. https://doi.org/10.1080/10473289.2007.10465301

802 Winnes, H., Fridell, E., 2009. Particle emissions from ships: Dependence on fuel type. 803 Journal of the Air \& Waste Management Association 59, 1391-1398.

804 https://doi.org/10.3155/1047-3289.59.12.1391

805 Wood, S.N., 2011. Fast stable restricted maximum likelihood and marginal likelihood 806 estimation of semiparametric generalized linear models. Journal of the Royal Statistical 807 Society: Series B (Statistical Methodology) 73, 3-36. https://doi.org/10.1111/j.1467808 9868.2010.00749.x

809 Ziegler, F., Hansson, P.-A., 2003. Emissions from fuel combustion in Swedish cod fishery. 810 Journal of Cleaner Production 11, 303-314. https://doi.org/10.1016/S0959-

811 6526(02)00050-1 